\title{
La intermitente invención de Sigüenza, personaje de Gabriel Miró (1908-1913)
}

\section{The Intermittent Invention of Sigüenza, Character of Gabriel Miró (1908-1913)}

\author{
Miguel Ángel Lozano Marco \\ Universidad de Alicante \\ ma.lozano@ua.es \\ ORCID iD: http://orcid.org/0000-0002-3694-2396
}

\section{RESUMEN}

El concepto que nos hemos ido formando de Sigüenza, personaje creado por Gabriel Miró, parece ser el resultado de la situación que los libros protagonizados por él ocupan en las Obras Completas, tal y como el escritor las dispuso a partir de 1926: una trilogía que acota su obra total, en cuyo centro viene a situarse Libro de Sigüenza, volumen recopilatorio cuyo contenido, si tenemos en cuenta las fechas añadidas en la edición de 1927, enlaza cronológicamente con los extremos. En realidad, la invención del personaje siguió un proceso intermitente: Sigüenza, años después de protagonizar Del vivir, fue apareciendo en diversos periódicos durante períodos breves y bien determinados, del primero de los cuales, el de su formación, nos ocupamos en las siguientes páginas.

Palabras Clave: Gabriel Miró; Sigüenza (personaje); evolución del personaje; literatura y periodismo.

\begin{abstract}
The concept built about Sigüenza, character created by Gabriel Miró, seems to be the result of the books' location featuring this character within his Complete Works, just like they were arranged by the writer from 1926. It is a trilogy that encloses his complete work. Libro de Sigüen$z a$ is a compilation volume placed in the middle of that trilogy and is chronologically linked both to the beginning and to the end, if we consider the dates added in the edition of 1927. Actually, the creation of the character followed and intermittent process. Sigüenza, years after Del vivir, appeared in different newspapers during short and well-defined periods. We'll deal with the first period, his training, in the following pages.
\end{abstract}

Key words: Gabriel Miró; Sigüenza (character); Character development; Literature and journalism. 
Conviene hacer hincapié en ello: la obra literaria de Gabriel Miró, desde sus primeras publicaciones en 1901 hasta que la muerte cortó sus proyectos en 1930, no es el resultado de una suma de títulos que van siendo producto de la inspiración del momento, sino más bien una especie de organismo textual que ha ido desarrollándose y evolucionando hasta encontrar una última forma en los años comprendidos entre 1926 y 1930, cuando el escritor revisa a fondo los textos para acomodarlos al plan de sus Obras Completas, tal y como lo concibe entonces para la editorial Biblioteca Nueva.

Dentro de ese organismo, en el que los temas van ampliando y modulando su sentido gracias a una forma derivada del criterio de «decir las cosas por insinuación» ${ }^{1}$, un sector peculiar lo constituyen los textos protagonizados por Sigüenza. De este se ha dicho - es un criterio extendido- que «coexistió siempre con Miró» (López Landeira 1972: 141), y la creencia de que el personaje es un alter ego de su autor parece confirmar esa idea. Pero nuestro conocimiento de Sigüenza ha dependido, hasta ahora, de la situación de sus libros en el conjunto de la obra del novelista. Como sabemos, Del vivir (escrito en 1903, terminado en 1904 y publicado en 1905) es el libro para el que fue creado, y Años y leguas (pensado en 1921, escrito desde 1923 hasta 1927 y publicado en 1928) es su culminación y despedida; ambos son libros unitarios que corresponden al encuentro con unos lugares y al retorno veinte años después. Vienen a señalar el momento inicial y el final de una producción literaria hacia cuyo centro se puede situar la tercera pieza, Libro de Sigüenza, publicado en 1917.

Este último es el que presenta más problemas: en principio, los que derivan de su condición de volumen de «páginas fragmentarias», de sus dos ediciones (dos versiones, en realidad) y de la cronología que se añade al final de cada capítulo en la versión definitiva. Como sabemos, Libro de Sigüenza, a diferencia de los otros dos, está formado con diversas crónicas publicadas en la prensa (Heraldo de Madrid, Diario de Barcelona, La Vanguardia, La Publicidad...) a lo largo de años. Hay, por tanto, una diversidad derivada de su dilatada cronología. Conviene precisar que el Libro que conocemos - el que siempre ha utilizado la crítica - es el revisado y organizado por su autor en 1927, muy diferente del que vio la luz diez años antes. El Libro de 1917 es una sucesión de treinta crónicas dispuestas sin ningún orden (ni cronológico, ni temático); el de 1927 está organizado en cinco secciones; la última recoge los textos publicados a su llegada a Madrid, en 1920, además de un añadido final: el comienzo de Años y leguas tal y como había aparecido en La Nación de Buenos Aires en 1923. Es en el contexto de las Obras Completas donde el escritor refuerza la relación entre los libros de esta trilogía.

\footnotetext{
${ }^{1}$ Así leemos en la breve nota autobiográfica situada al inicio del tomo I de la Edición Conmemorativa de sus Obras Completas, Barcelona, Tipografía Altés, 1932, p. X.
} 
Pero también es en esta última versión donde Miró añade a cada uno de sus treinta y tres capítulos - llamemos así a cada una de las crónicas cuando aparecen dispuestas en la organización del volumen - sendas fechas que corresponderían a las de su escritura; y esto es lo que ha afectado a la tarea de los críticos que han pretendido examinar la evolución del arte mironiano. Estas fechas son inciertas, como ya lo advirtiera Pedro Caravia Hevia en el apartado de «Variantes y notas» del volumen correspondiente —el séptimo - de la llamada Edición Conmemorativa, dándose casos de encontrar muchos años de diferencia entre esa supuesta fecha de composición y la de su publicación en la prensa (lo que resulta absurdo): crónicas publicadas en 1912 o 1913 y, con seguridad, escritas en esos años, figuran en el Libro como de 1903. Se equivocan, pues, quienes sitúan en la época de redacción de Del vivir textos escritos en el momento en que comienza a concebir y gestar El obispo leproso ${ }^{2}$.

Pero además, si atendemos a la cronología real, la de su publicación (la única fiable de que disponemos), podemos comprobar que Sigüenza es un personaje utilizado en breves y discontinuos períodos: es concebido a propósito para Del vivir, como necesidad técnica y estética (Lozano Marco 2005a: 494-499), y no reaparece hasta cuatro años después, por un breve período y con escasos textos. En realidad, Sigüenza viene a ser una invención discontinua que corresponde a momentos fácilmente identificados: 1908-1910; 1912-1914, y $1920^{3}$. A partir de 1923 irrumpe de nuevo para, después de cinco años de ir apareciendo en La Nación de Buenos Aires y en El Sol de Madrid, principalmente, con textos reescritos y modificados, alcanzar su plenitud en el libro más personal del escritor levantino: Años y leguas.

Nos ocupamos aquí de lo que viene a ser un segundo período en la invención de Sigüenza, el que se abre cuatro años después de haber protagonizado el libro para el que fue concebido. Esto es: desde su primera recuperación, en diciembre de 1908, hasta el momento en el que el personaje se consolida y adquiere el carácter que le da una trayectoria, un pasado y unos datos biográficos que vienen a corresponder con los de su creador, lo que sucede a partir de finales de 1912.

Para mayor claridad, ordeno la relación de las 26 crónicas (o artículos, relatos...), señalando su primer título, el periódico en el que fueron publicadas y la fecha de su aparición; entre corchetes figura la fecha que le atribuye el escritor cuando las incorpora a la versión definitiva, la de 1927. Las siglas DHP hacen referencia al volumen de cuentos Del huerto provinciano (1912) y GS

${ }^{2}$ Lo que viene a suponer un cambio de época. Gracias al Epistolario, sabemos que en noviembre de 1912 escribe a su amigo Enrique Puigcerver informándole sobre la próxima publicación de una novela que iba a titularse El obispo leproso y la loca (Miró 2009: 131).

${ }^{3}$ En este año, Miró se traslada con su familia a Madrid. Para tratar sobre ese cambio importante en su vida, recupera a su personaje, quien protagoniza solo cuatro crónicas que envía a La Publicidad de Barcelona (Lozano Marco: 2005b). 
al tomito preparado por Clemencia Miró, Glosas de Sigüenza (1952); con la abreviatura Alt se alude al libro de Marta E. Altisent (1992).

PRIMERA RECUPERACIÓN (1908-1910)

1. «Notas de Sigüenza», Prometeo, I, 2 (diciembre 1908). DHP.

2. «Sigüenza, el Herrero y el Juez», Heraldo de Madrid, 21 de diciembre de 1908.

3. «Comento del domingo», Diario de Alicante, 4 de enero de 1909.

4. «Un vagar de Sigüenza», Los Lunes de El Imparcial, 7 de junio de 1909 [1908]. DHP y LS, 1927: «Otra tarde. La gaviota».

5. «Sigüenza y los señores concejales», Diario de Alicante, 4 de septiembre de 1909.

6. «Glosas de Sigüenza», Heraldo de Madrid, 13 de abril de 1910. GS.

RELATOS ADAPTADOS (1911-1912)

7. «Mi tía», Caras y Caretas, 25 de marzo de 1911 [1910]. LS: «Sigüenza habla de su tía».

8. «Pláticas.-De una que tuvimos un capellán de monjas y yo», Diario de Barcelona, 18 de octubre de 1911 [1909]. LS: «Plática que tuvo Sigüenza con un capellán».

9. «Pláticas.-Figuritas de Belén», Diario de Barcelona, 24 de diciembre de 1911 [1906]. LS: «Pastorcitos rotos».

10. «Pláticas.-De los balcones y portales», Diario de Barcelona, 29 de marzo de 1912 [1903]. LS.

11. «Pláticas.-Relato de un viaje de novios», Diario de Barcelona, 20 de julio de 1912 [1908]. LS: «Un viaje de novios».

SEGUNDA RECUPERACIÓN, CON TRES RELATOS ADAPTADOS (1912-1913)

12. «Levante.-El Sr. Cuenca y su sucesor», Los Lunes de El Imparcial, 25 de noviembre de 1912 [1908]. LS.

13. «De la crueldad de Sigüenza», Diario de Barcelona, 25 de diciembre de 1912. GS.

14. «Un envidiado caballero de Levante», Diario de Barcelona, 25 de enero de 1913 [1909]. LS: «Un envidiado caballero».

15. «Sigüenza, opositor», Diario de Barcelona, 1 de febrero de 1913 [1907]. $L S:$ «El señor de Escalona».

16. «Una mañana levantina», Diario de Barcelona, 4 de marzo de 1913 [1910]. $L S:$ «Una mañana».

17. «Los almendros y el acanto», Diario de Barcelona, 27 de marzo de 1913 [1906]. $L S$.

18. «Un artículo de Sigüenza», Diario de Barcelona, 15 de abril de 1913 [1909]. $L S:$ «Una jornada del Tiro de pichón».

19. «El pececillo del P. Guardián», Diario de Barcelona, 30 de abril de 1913 [1909]. LS. Adaptado.

20. «Plática.-Asuntos crematísticos», Diario de Barcelona, 13 de junio de 1913. Alt.

21. «En Cristianía», Diario de Barcelona, 25 de junio de 1913 [1910]. LS: «Una noche (En Cristianía)». 
22. «Figuras que todos conocemos.-La señora que hace dulces», Diario de Barcelona, 23 de julio de 1913 [1909]. LS. Adaptado.

23. «Pláticas.-Cosas viejas y sabidas», Diario de Barcelona, 2 de agosto de 1913. Alt.

24. «Figuras de nuestra vida.-El señor de los ataques», Diario de Barcelona, 23 de agosto de 1913 [1903]. LS. Adaptado.

25. «Levante.-Sigüenza, el ganado y el cordero», Los Lunes de El Imparcial, 1 de septiembre de 1913 [1903]. LS: «Sigüenza, el pastor y el cordero».

26. «Una tarde». No encontramos su publicación en periódico. Aparece en la primera versión de $L S$ [1909].

\section{PRIMERA RECUPERACIÓN (1908-1910)}

Como hemos apuntado, Gabriel Miró tarda cuatro años en recuperar al protagonista de Del vivir y, cuando lo hace, no lo recrea con asiduidad: desde diciembre de 1908 hasta abril de 1910 lo utiliza solo en seis crónicas. Parece que no se afianza en su imaginación, pues lo vuelve a olvidar de nuevo durante más de dos años, hasta finales de 1912. Esas seis primeras crónicas corresponden al momento en que el escritor alicantino ha logrado una cierta fama en Madrid, después de ganar con Nómada el premio convocado por «El Cuento Semanal» y de publicar La novela de mi amigo; conviven con la escritura de novelas cortas como La palma rota, El hijo santo, Amores de Antón Hernando (las tres en «Los Contemporáneos», en 1909), y, sobre todo, con la gestación de la novela en la que puso toda su ambición de juventud, Las cerezas del cementerio (1910), entre otros proyectos que tardarán algo más en ver la luz ${ }^{4}$.

He calificado estos seis breves textos de «crónicas» porque es el término que les conviene, y el que el autor emplea cuando se refiere a este sector de su producción. En el borrador del prologuillo a la primera edición del Libro (1917), el escritor se califica a sí mismo como cronista de Sigüenza, y así lo reitera en otros lugares ${ }^{5}$. La crónica es un subgénero literario en prosa, de breves dimensiones, propio de la prensa periódica, que adquirió vitalidad y originalidad en la época. El profesor José-Carlos Mainer la caracteriza de manera precisa cuando escribe que los mejores ejemplos vienen a ser una «mezcla afortunada de impresión vivida, cuento inconcluso y ensayo personal» (Mainer 1975: 39), y esos tres elementos son los que predominan en estos escritos y los

${ }^{4}$ En 1910 anuncia como de próxima aparición Dentro del cercado, que no será publicada hasta 1916 (Lozano Marco 1979: 108). Hay que añadir que en esos años tradujo del francés las novelas El señor de Halleborg, de Alfreed von Hedenstjerna (Barcelona, Doménech 1910), y Su Majestad, de Henry Lavedan (Barcelona, Doménech 1911).

${ }^{5}$ En «Sigüenza, los peluqueros y la muerte» (La Vanguardia, 4 de febrero de 1914), escribe, refiriéndose a la serie: «La crónica que aquí se va tejiendo de algunas emociones de Sigüenza». 
definen: Sigüenza es un flâneur que divaga por calles, campos y lugares cercanos a su ciudad para conocer, observar, oír..., y dar materia al escritor para que traslade sus impresiones al papel; el cuento es un género afín, y en estas prosas hay casi siempre una especie de relato adelgazado, lo que justifica que el escritor incluyera un par de ellas en un volumen recopilatorio, Del huerto provinciano, publicado en 1912; en lo que se refiere al ensayo, en todas predomina el elemento meditativo, se tiende a suscitar reflexiones, como las que se van anotando a partir de esas «impresiones vividas». No hay que considerar esos tres elementos por separado, sino integrados en una unidad literaria en la que se nos muestra a un personaje viviendo en unas circunstancias similares a las que pudiera haber vivido su creador.

Porque lo que nos va apareciendo en esas primeras crónicas es la vida provinciana de Alicante y de su entorno: una realidad «municipal y espesa» que el escritor sabe tratar con una sutil mezcla de ironía y de lirismo, en un juego de alejamiento-cercanía con respecto a lo más cotidiano, opaco y vulgar; algo cercano a lo que Azorín acababa de conseguir en un bello libro, el primero que firma con su famoso seudónimo, Los pueblos (Ensayos sobre la vida provinciana $)^{6}$, volumen construido con diversas crónicas, relatos, ensayos..., que había aparecido a comienzos de 1905, donde un Azorín personaje, que procede de sus anteriores novelas, pasea por Petrel, Esquivias, Santander, balnearios del Norte, y sobre todo por Monóvar, su pueblo. Sigüenza, como Miró, no sale de su ciudad y alrededores, y con su experiencia sabe captar el ambiente moral, junto con los sentimientos y anhelos del solitario espectador.

Las seis crónicas son similares, aunque de distinto alcance; cuatro de ellas — las más extensas - fueron escritas para periódicos de Madrid; las otras, más dependientes de sucesos lugareños, para la prensa local. De todas ellas solo una, «Un vagar de Sigüenza», fue a parar al Libro, pero en la edición de 1927 — con el título «Otra tarde (La gaviota)»_- y esta, junto con la primera, son las recogidas en el volumen de cuentos Del huerto provinciano (1912); las otras cuatro fueron olvidadas por el escritor.

La primera crónica, la que supone la recuperación de Sigüenza como personaje, es seguramente la que vio la luz en el número dos de la revista de Ramón Gómez de la Serna, Prometeo, en diciembre de 1908. En ese mismo mes, el día veintiuno, aparece en Heraldo de Madrid la titulada «Sigüenza, el Herrero y el juez», basada en un suceso real del que dio cuenta la prensa en el día anterior, y se amplía con nueva información en el mismo número en el que

\footnotetext{
${ }^{6}$ No se encuentra ejemplar de este libro en la biblioteca de Miró, tal y como la conocemos; pero dada la admiración que Miró sentía por Martínez Ruiz, lo más probable es que leyera este «pequeño libro» que tanta fama dio entonces a su autor. Sigüenza es muy diferente del Azorín personaje, del mismo modo que lo es el estilo y la actitud desde la que recrean lo cotidiano, más apasionada, vibrante y dolorida en el joven alicantino.
} 
aparece el texto de Miró7; tuvo que ser redactado el mismo día veinte. De este modo, siendo Prometeo una revista mensual, y el texto que en ella aparece la crónica de un domingo - cualquier domingo- provinciano, se supone que debió haber sido enviado con anterioridad a Madrid, pues las revistas van recogiendo su material durante semanas, antes de llevar los textos a la imprenta. Hago hincapié en ello porque suele la crítica dar prioridad a la de Heraldo de Madrid sobre la de Prometeo, cuando esta habría sido escrita por lo menos un mes antes que aquella. El orden de publicación es el que nos puede guiar: el que figura en la relación cronológica.

«Notas de Sigüenza» es, además, el texto en el que el narrador hace especial hincapié en identificar al personaje que allí aparece con el que anduvo por los campos de Parcent. Cuando se nos muestra al fondo de una estampa, siguiendo a un grupo de mujeres, el narrador lo presenta como «un hombre que viste luto de rigor. Es Sigüenza, aquel apartadizo que recorrió los parajes leprosos levantinos» (Miró 2007: 163). Esta crónica de sucesos vulgares se asemeja en tono y sentido a Del vivir. De muy leve asunto: Sigüenza sigue a un grupo de mujeres que se aburren en la tarde del domingo y deciden pasear hasta el cementerio, para entretenerse. Hay una excelente ambientación del domingo provinciano - tema frecuente en la época modernista - y una atención al carácter de estas mujeres, que ven engaño en la súplica de unos mendigos y consideran «farsa de desgracia» los lamentos que una mujer pobre, acompañada por un rapacillo, hace ante una tumba. La visión del cementerio, la consideración de la muerte, y aún más, la de los muertos, en la tranquila tarde, a la vista del mar inmenso, produce un contraste que se acusa más en el momento en que el personaje, después de atravesar un estrecho pasadizo, llega al cementerio de los pobres: «Le recibe toda la tarde, ancha, libre, dulce en sus confines de montañas azules, resignada en la soledad de las llanuras aradas, melancólica en las umbrías» (ibid.: 166). El tratamiento del espacio produce esta emoción de amplitud al dar dimensión física a la tarde mostrando como totalidad integradora aquello que se percibe unido a los sentimientos que suscita; en la creación de estas sensaciones espaciales el escritor es un maestro desde fechas muy tempranas.

${ }^{7}$ Esta crónica, olvidada por su autor, fue recuperada por el diario El País, el 28 de diciembre de 1980, junto con unas cartas. El prof. Gregorio Torres Nebrera, en su excelente edición de Corpus y otros cuentos (1995), recoge, además de los seleccionados por Miró bajo ese rótulo, todos los escritos por su autor, exceptuando los de El ángel, el molino, el caracol del faro. Incluye el texto que nos ocupa, del mismo modo que los que fueron incluidos en el volumen de cuentos Del huerto provinciano, y enriquece la edición y anotación de esta crónica-relato con la reproducción de los artículos periodísticos que informaban sobre la detención del delincuente en el mismo periódico Heraldo de Madrid, los días veinte y veintiuno de diciembre de 1908, coincidiendo el segundo artículo con la recreación literaria del mismo suceso (véanse las págs. 400-405). 
El relato viene a ser la crónica de una cotidianeidad vulgar, en la que se indaga en sentimientos y actitudes fundamentales: la tristeza que producen los domingos, con su ambiente detenido, frente al ansia viajera; el interés morboso que producen la muerte y los muertos, al margen de todo ascetismo o consideración moral o filosófica — esos muertos son ajenos-; pero sobre todas estas consideraciones prevalece lo contemplado en el grupo de mujeres: sus reacciones de desconfianza ante los mendigos y ante la mujer afligida junto a una tumba humilde: «¿No descubre esto en nosotros raíces de crueldad, deseo de que sea cierta la desventura e incesante en su opresión?» (ibid.: 167). En una escena anodina encuentra el protagonista sentimientos y actitudes muy semejantes a las halladas en Del vivir: el interés morboso gratuito y una crueldad cotidiana como impulso espontáneo que revela la falta de amor. El personaje introduce la reflexión, solidaria de la sensibilidad que capta el ambiente, los matices de la tarde y la emoción del espacio.

«Sigüenza, el Herrero y el juez» es la breve crónica de un suceso que se había producido el día anterior. Fue publicada en Heraldo de Madrid el 21 de diciembre de 1908, junto con la segunda parte de la noticia periodística que informaba sobre el hecho: la detención en el pueblo de San Vicente del Raspeig, muy cercano de Alicante, de un famoso delincuente apodado «el Herrero». De este modo coinciden en el mismo diario la información escueta y su versión literaria, que aporta ironía y hondura a la noticia. La lectura de ambos textos permite comprobar cómo el arte de Miró, que toma su materia de la realidad, la trasciende, y eleva a una dimensión ético-estética lo que en su versión convencional es una nota de sucesos. La crónica se transforma en relato que, sin traicionar la realidad de la que parte, alcanza una notable autonomía. Siendo un texto excelente, el escritor lo dejó en el lugar de su aparición sin acomodarlo en un volumen, tal vez por su estrecha dependencia del suceso real.

Miró ha aprendido a ver desde Sigüenza y maneja a su personaje con soltura. Más que en la crónica anterior, en la que la atención al grupo femenino y la exposición de ideas iba dejando en la sombra al solitario paseante, logra aquí una adecuación entre todos los elementos, focalizados en la conciencia del protagonista. Una tercera persona narrativa da cuenta del suceso a partir de la sensibilidad aneja a una conciencia receptiva.

El relato, en su concepción y desarrollo, es de notable originalidad: presenta la detención del forajido, no de manera directa, sino por reflejo en relato ajeno recogido por Sigüenza. Son varios filtros los que debemos atravesar para llegar a la escena: el narrador nos cuenta que Sigüenza, al enterarse de que en la vecina población de San Vicente ha sido detenido el famoso bandido por un viejo alguacil, un consumero fornido y un juez «romántico», toma el tranvía para ir allí a ver — reacción que ha de ser analizada por el escrupuloso personaje - . Por el camino, se cruza con el carro en el que la Guarida Civil traslada al detenido a la capital; un chasco muy habitual en Sigüenza. Cuando llega a San Vicente, un amigo le relata la escena de la detención, con sus detalles 
fundamentales: el delincuente, al verse sorprendido, empuña una pistola, y es el joven y modesto juez municipal quien se la hace soltar dándole un terrible mordisco en la mano.

El suceso dramático termina de manera irónica, combinada con cierta ternura. Pero no es este el efecto que persigue el escritor. El relato tiene matices de sensibilidad y ligeros apuntes líricos dentro de la ironía total. En el caso de Sigüenza, lo que encontramos es, como en Del vivir, una reflexión sobre las razones de su viaje: ¿es por egoísmo de curioso, o por piedad?, ¿hay algo de crueldad en su deseo de ver al miserable? Sigüenza es, como sabemos, un personaje escrupuloso, que se analiza para conocer los motivos y las consecuencias de sus acciones, y más aún: para descubrir la pureza o los componentes egoístas de sus intenciones ${ }^{8}$. Sus impulsos y deseos tienen un sentido susceptible de ser enjuiciado desde criterios opuestos. La actitud del personaje puede influir en el lector, si está atento, e incitarlo también al análisis de sus reacciones y a tomar conciencia de sus contradicciones.

En el relato de la detención, en sus precedentes y consecuencias, hay dos elementos que destacan: el primero es el sutil toque de compasión hacia el delincuente, que se convierte en víctima; el malhechor esta dibujado con los suficientes rasgos de humanidad como para que veamos en él a un solitario fatigado y acosado. La mirada es piadosa, mientras que el grupo de los captores está dibujado con un toque caricaturesco, subrayado por la manera de relatar el acecho, el forcejeo y el mordisco. El suceso real cobra vida literaria al unir esos dos elementos: la compasión y la ironía en la escena de la detención; una escena en la que la insistencia en lo cotidiano resta énfasis «heroico» al momento culminante. Un tercer elemento es la fusión de los dos anteriores en la ternura con la que es contemplado el joven juez municipal: el narrador $-\mathrm{y}$ el personaje - saben que el juez se quiere casar, pero que la humildad de su cargo no se lo permite. Ahora ha adquirido la notoriedad con la que soñaba, pero no por su pluma ni por su verbo, sino por su «heroico mordisco». La ironía encierra un toque de piedad, y todo se disuelve en ese ambiente provinciano que el escritor recrea con mezcla de cercanía afectiva y distancia crítica. Las primeras crónicas desarrollan su acción en este ambiente pequeño y cerrado, pero también en medio de una naturaleza que engendra los mejores sentimientos y suscita las más nobles ideas. Desde sus primeros escritos, Gabriel Miró se nos muestra irónico ante la sociedad, y lírico e íntimo ante la naturaleza, como apuntara certeramente Jorge Guillén ${ }^{9}$.

También la ironía es el sustrato de «Comento del domingo», crónica que nunca salió del Diario de Alicante por tratarse de un texto de cortos vuelos. Es

${ }^{8}$ Como en el caso de Del vivir, el personaje se cuestiona su proceder: «¿Por qué fue él a esos pueblos levantinos? Amor no le llevó, sino la sed de ver.» (Miró 2006: 336)

9 «Miró es frente a la Naturaleza un sensitivo entusiasta; frente a la sociedad, un sensitivo malicioso. De ahí la importancia de la ironía.» (Guillén 1969: 178) 
una consecuencia de la anterior, y fue publicada siete días después: Sigüenza, junto con sus amigos, vuelve a San Vicente para presenciar la entrega de recompensas y mercedes a los captores, pero una vez llegados al pueblo se enteran de que el acto ha tenido lugar en Alicante; un chasco similar al anterior. La presencia del ambiente y una acción secundaria - el nacimiento de un cabritillo - dan cuerpo y vida a este breve relato que guarda en su seno una lección ética, para quien sepa leerla: la recompensa lograda es «una alegría brotada de las raíces del dolor» ${ }^{10}$.

Es evidente que hay una diferencia notable entre las crónicas redactadas para la prensa local y las publicadas en los periódicos de Madrid. «Sigüenza y los señores concejales» tiene un interés estrictamente local: el protagonista asiste en el Ayuntamiento a la sesión en la que se adjudica al escultor Vicente Bañuls (amigo del escritor) una plaza de delineante municipal. Lo más destacado es la galería de retratos de concejales que, con detalles significativos y mirada crítica, cobran vida moral, pero también física, siempre con el inevitable tono irónico ${ }^{11}$.

Más interés tiene la que le precede: una colaboración en Los Lunes de El Imparcial. Aparece en esa publicación madrileña la única de estas crónicas que ha de figurar en el Libro de Sigüenza, pero no en su primera versión, sino en la definitiva, en 1927. La razón puede estar en el hecho de que ya hubiera sido recogida en Del huerto provinciano, libro de 1912, fecha que en 1917 aún parecía cercana, pero no diez años después. El título primero, «Un vagar de Sigüenza», es sustituido por el de «Otra tarde (La gaviota)» en su versión definitiva. Ocupa así un lugar en la sección «Muelles y mar»y, aunque sea muy anterior a las otras piezas, no desentona en el conjunto al ser revisada a fondo, casi reescrita. Fiel a su designio de «decir las cosas por insinuación», el autor aligera masa textual y elimina escenas con algún personaje secundario para centrarse en una leve anécdota que funciona como parábola: Sigüenza envidia la libertad de las gaviotas, pero un amigo socarrón, Martínez, le lleva a ver una, domesticada por un zapatero remendón, que dormita en su portal y se alimenta de los garbanzos del cocido. Después, la visión de un barco velero despierta en el personaje sueños ideales, y sufre de nuevo la rectificación de su compañero quien, ateniéndose a la realidad, le dice que más que de ideales, el barco viene cargado de bacalao.

Con su punzada humorística, los contrastes y las aparentes decepciones, apunta un tema que el escritor está desarrollando en esos días en Las cerezas del cementerio: el desengaño que sufre una imaginación idealizadora ante la realidad, y la enseñanza que de ello resulta. El asunto del relato es uno de los relevantes en su pensamiento y en su obra, y lo hemos de encontrar matizado,

10 Diario de Alicante, 28 de diciembre de 1908.

11 Diario de Alicante, 4 de septiembre de 1909. 
con diversas modulaciones, hasta llegar a la madura aceptación de sí mismo al reconocer que su personalidad viene a ser, en buena parte, el resultado de una sucesión de anhelos incumplidos. En el centro del relato se sitúa la expresión del mayor anhelo: el deseo de alcanzar plenitud en una vida que malgastamos en pequeñeces y mezquindades cotidianas, y este lamento queda formulado, con melancólica ironía, en su referencia evangélica: nacemos para altos designios — viene a decirnos Sigüenza - , pero solo nos afanamos para lograr aquello que el Evangelio dice que se nos ha de dar por añadidura. De este sentimiento, bien arraigado en su conciencia, nace el anhelo por la verdad que encierra y la decepción ante las inevitables obligaciones cotidianas; contraste fatal entre el noble impulso y las mezquinas exigencias que impiden al hombre encontrarse a sí mismo, algo que para el autor constituía una acuciante realidad.

«Glosas de Sigüenza» es el título, algo general, con el que cierra esta primera y breve época de recuperación del personaje. Es también el título que Clemencia Miró dio al libro recopilatorio (1952) donde queda recogida. Son glosas de una frase de Gracián relativa al comportamiento del hombre de «gran capacidad», quien se mantiene siempre superior a toda «vulgar alternación de los humores ni aun de los afectos» (Miró 1952: 20). La frase contraría a Sigüenza, a quien un simple olor produce alteración; pero no la glosa con razonamientos a la manera ensayística, sino con el relato de los sucesos de un día, un domingo. En ellos hay suficiente materia como para entender las absurdas vanidades y egoísmos de los hombres, y su espontánea crueldad, con frecuencia inconsciente, tal y como lo contempla en el casino, en la corrida de toros a la que asiste, y en la «inocente costumbre» de cazar gorriones con que distraen su ocio los habitantes de los campos cercanos. Cualquier día nos provee de documentos sobre la ubicuidad del egoísmo y de la crueldad con apariencia de comportamiento anodino e inocente. Al final de la crónica, una noticia leída en el periódico impresiona a Sigüenza: un hombre ha volado en aeroplano desde Francia hasta Inglaterra. Al soñador levantino la empresa le parece audaz y hermosa, digna de un «arcángel» o de un «artista supremo», y le hace imaginar la emoción del vuelo; pero al final la sorpresa derriba su castillo de naipes: el «arcángel» no voló por sentir la emoción suprema, sino por ganar una apuesta. Esta anécdota le lleva a pensar que posiblemente Gracián tuviera razón.

En las mejores crónicas, las publicadas en Prometeo, en Heraldo de Madrid y en Los lunes de El Imparcial, el escritor logra, desde el fundamento de la experiencia vivida, elevarse hasta la reflexión moral y la nota poética mediante un relato sostenido por la figura de su protagonista. Pero en este breve período no podemos hablar de constancia ni de asiduidad: las tres primeras crónicas aparecen en el mismo mes, en diciembre de 1908, mientras que las tres siguientes se van distanciando: se publican en junio y septiembre de 1909, y en abril del siguiente año. Es curioso ver cómo Gabriel Miró, que ha logrado manejar con destreza un personaje con muchas posibilidades, apto para realizar un complejo juego de acercamiento y alejamiento, ironía y lirismo, lo olvida 
de nuevo durante una temporada: desde abril de 1910 hasta finales de 1912; pero cuando reaparece es ya un personaje maduro, con biografía, con pasado y con los rasgos sustanciales que irá enriqueciendo hasta el final.

\section{ReLATOS ADAPTADOS (1911-1912)}

Como acabamos de apuntar, Sigüenza vuelve a desaparecer después de que el escritor lo hubiera recuperado para protagonizar esas seis crónicas; la razón puede estar en el agotamiento de una fórmula. Es posible que el escritor creyera repetirse en un esquema reiterado: un protagonista pasivo, espectador, está presente en una sucesión de escenas de carácter cotidiano, aunque significativas, o se hace eco de un suceso «extraordinario» que altera la paz lugareña. Miró ha logrado captar, con notable ironía y un punto de lirismo, esa vida provinciana que viene a ser uno de los motivos literarios relevantes en la época modernista: la temática alrededor de la cual Rafael Cansinos-Assens (1925: 225-244) construyó toda una escuela de «cantores de la provincia», uno de los cuales, y de mayor hondura, es nuestro autor. Es posible que esa misma monotonía, y casi repetición, que vemos en los títulos, revele el mencionado sentimiento: «Notas de Sigüenza», «Un vagar de Sigüenza», «Glosas de Sigüenza». Entre las «notas» iniciales y las «glosas» finales se desarrolla un corto período de crónicas literarias. Cuando reaparezca el personaje, a finales de 1912, no será ya un flâneur, sino el protagonista de espléndidos relatos, cuya vida abarca mayor ámbito que el que se recoge en esas páginas.

Desde abril de 1910 hasta noviembre de 1912 se extiende, pues, un período en el que Sigüenza está ausente de la prensa periódica; pero en el Libro aparecen cinco relatos publicados en estas fechas: se trata de cuentos, narrados en su origen en primera persona, que fueron modificados en 1917 para incorporar al personaje de Sigüenza y adaptarlos así a la serie, introduciendo en casi todos ellos un narrador. Los cinco forman parte de la sección central de 1927, «Días y gentes», y participan de la temática que venimos encontrando en los textos de Sigüenza: la falta de amor, el egoísmo, la falsa compasión, la crueldad..., en diversas formas y modalidades. En suma, una cierta variedad en la modulación de temas y de motivos para mostrar algunos rasgos esenciales del comportamiento humano.

El primer cuento es el de menos enjundia: «Mi tía» se llamaba en su primera salida, y fue la primera colaboración del alicantino en la revista Caras y caretas de Buenos Aires ${ }^{12}$. Toda la adaptación a la serie sigüencina se reduce al cambio de título, «Sigüenza habla de su tía», y a una breve interpolación con la intervención de un personaje que se dirige al protagonista llamándolo

1225 de marzo de 1911. Ocupa una página, y contiene una ilustración de Peláez. 
por su nombre: «señor Sigüenza». Este relato es una excepción en el libro, por ser el único que conserva la forma original en primera persona: el narrador es el personaje, cuando es común, y casi obligado - y hasta rasgo de estilo- que los textos de Sigüenza sean narrados en tercera persona; aunque sucede que la fuerza del personaje crea en el lector la impresión de la primera, y algún comentarista ha caído en este error.

Es esta la pieza más endeble del futuro libro; es el relato de una decepción, un chasco, y también un texto anticlerical: al protagonista le informan de que su anciana tía - señora muy piadosa - se ha preocupado por él en su testamento. Cuando ella muere, se entera de que su fortuna ha sido legada a varias parroquias con el propósito de que la mitad de las misas sufragadas con ese dinero sean aplicadas a la salvación del alma de su sobrino ${ }^{13}$. En la versión de Libro de Sigüenza se añaden unos párrafos que incrementan la nota anticlerical, reforzando caricaturescamente la voracidad de los sacerdotes.

El segundo de los relatos adaptados, «Pláticas.-De una que tuvimos un capellán de monjas y yo», formaba parte de una serie que estaba publicando Miró en Diario de Barcelona desde 1911 con ese título genérico, a la que pertenecen también los tres cuentos siguientes. Esta «Plática» se transforma en un cuento de situación, narrado en tercera persona, «Plática que tuvo Sigüenza con un capellán», y presenta una escena de significación muy sigüencina: es la recreación de la paz de la tarde, en ambiente provinciano, donde un copioso averío y otros animales conviven en calma en el arroyo, a las afueras de la población. Sigüenza conversa con un capellán que ha sido soldado, y tratan sobre lo que la escena sugiere: paz, concordia... El capellán cita a Fray Luis de Granada para iniciar una reflexión sobre lo que debemos aprender «en el gran libro de la Creación»: el sosiego y el amoroso júbilo que muestran «estos palomos, pavos y gallinas, con macho y todo» (Miró 2008: 574). El capellán recuerda sus años de soldado en Ultramar, y la reflexión que hizo en otra hermosa tarde, en mitad de una lucha en la que los hombres se mataban bajo la pureza del cielo y en medio de la belleza del paisaje. Aquellos animales nos daban una lección. Pero la verdadera lección se produce cuando, de improviso, la buena avenencia del averío se transforma en estruendo de pelea, y todo porque habían descubierto un «gusanico muerto» por el que contienden.

La naturaleza nos da su lección: las criaturas pueden ser buenas cuando el ambiente es propicio y las circunstancias les son favorables; hasta que aparece un «hecho» que lo muda todo. El relato es un «ejemplo»; recoge una lección presente en Del vivir: el mal, la crueldad, el egoísmo, es un elemento inheren-

${ }^{13}$ Edmund L. King (1999: 33), informa: «es un hecho bien conocido en la familia que no fue Sigüenza/Gabriel sino el hermano de Miró, Juan, quien era el beneficiario del testamento de la señora fallecida en «Sigüenza habla de su tía». Es un dato que nos ayuda a entender la manera en que el escritor va tomando sucesos de la realidad para transformarlos en una verdad estética. 
te a la naturaleza, y su presencia la advertimos hasta en aquello de apariencia más inocente.

«Figuritas de Belén», que ha de quedar incorporada al libro con un título más explícito, «Pastorcitos rotos», es una página de Navidad, reformada con sólo sustituir en un par de ocasiones a un innominado «padre» por Sigüenza. Más que de un cuento, se trata de una página lírica y melancólica, una meditación sobre el paso del tiempo materializado en el deterioro de las figuritas, y sobre las renovadas ilusiones y tristezas de las sucesivas generaciones, que reconocen en las figuras viejas su pasado, o en las nuevas su futuro ${ }^{14}$.

El más sigüencino de estos cinco relatos es, sin duda, «De los balcones y portales». Es un texto que enlaza perfectamente al viajero de Del vivir con el contemplativo veraneante de Años y leguas. El protagonista de este relato, en su primera versión, es un «yo narrador» que, como Sigüenza, viaja en jumento por las comarcas levantinas y gusta de sus paisajes. En el texto definitivo se suprime un párrafo inicial donde se glosa la «emoción del paisaje» desde la primera persona del autor:

Yo os digo que cuando me asomaba a una cumbre nueva, que durante mucho tiempo la viera toda recatada en un suave misterio de cendales de humos y nieblas azules de distancia, o cuando descansaba en el resistero de un puerto umbroso, o recibía la emoción de paz y de inocencia y los olores de huerta, de tierra mojada, de herreñal, de pinares de los generosos llanos, así entonces me acordaba yo de los incentivos y grandezas de las más famosas ciudades del mundo como de las preeminencias de diputado o ministro del Tribunal de Cuentas, oficio este último, para mí, el más laberíntico, costoso y terrible. ¿Tribunal de Cuentas? Ni estudiando Derecho Administrativo — pues ¡claro que soy abogado también! — me aventuré a saber lo que eso era ${ }^{15}$.

Las frases finales restan eficacia lírica al fragmento, pero tienen el interés de mostrarnos, en un espontáneo arranque, al autor, incorporando un dato biográfico que no ha de traspasar al personaje. El texto completo del relato se encuentra más cerca de Años y leguas por el motivo que recrea: el de las viejas señoras que viven de espaldas a la vida, y de ahí su mezquindad. Toda la moral se resume en la imagen de las ventanas tapiadas de la casa. Como en el caso de «Doña Elisa y la eternidad», las ventanas cegadas privan del «goce de anchura, de visión campesina», y esto explica la mezquindad «de aquel vivir siempre murado y tenebroso» (Miró 2008: 568). La anécdota reveladora de esa mezquindad es captada sutilmente por el visitante: una niña acude con un tarro

14 Tratándose de un texto escrito para la Navidad, carece de sentido que fuera redactado en 1906 y que lo guardara hasta su publicación, el 24 de diciembre de 1911, con varias navidades entre ambas fechas. Lo lógico es que fuera compuesto poco antes de su aparición en las páginas de Diario de Barcelona.

15 Diario de Barcelona, 29 de marzo de 1912. 
a la señora de la casa en demanda de miel; cuando la señora ha puesto «una dedada» y va a entregarlo a la niña, se detiene, lo piensa mejor, y le quita un poco. Es un relato sobre el egoísmo imperceptible que descubrimos en pequeñas acciones, y este carácter mezquino se compadece con una vida cerrada, indiferente a la visión gozosa de la naturaleza. El final, por oposición, traza el espectáculo del que goza el protagonista desde sus balcones, abiertos frente al mar. En la primera versión (Diario de Barcelona) leemos: «Por mis balcones gozo yo de lo inmenso, y en esa llanada infinita del mar parece que se acostaba dichosamente mi alma en los momentos en que el dolor reducía mi cuerpo».

En la versión definitiva se sustituye la primera por la tercera persona: el «gozo yo» por «goza Sigüenza»; «llanada» se convierte en «llama», «acostaba» en «acueste», y se suprime lo que figura en cursiva.

He copiado este párrafo no solo por ser un ejemplo de la adaptación, sino porque puede servir para fechar el texto. En la versión definitiva del Libro (1927) aparece este relato como de 1903, de modo que sería coetáneo de Del vivir, e incluso anterior a él; pero se publica en Diario de Barcelona en marzo de 1912. No tiene sentido que el escritor conserve guardado durante nueve años un texto como este; pero aparecen en esa primera versión un par de datos objetivos, que son suprimidos en las siguientes: en primer lugar, la referencia al «dolor» que «reducía mi cuerpo» tiene su explicación en una fístula que padeció Gabriel Miró en 1912, de la que se queja en diversas cartas de ese año, y de la que finalmente fue tratado por cirujanos (Ramos 1996: 334). El dolor tiene esa referencia, al igual que la aliviadora visión desde sus balcones tiene otra referencia en una frase suprimida desde 1917: «Los míos [mis balcones] en esta nueva casa que ahora busqué, se abren frente al mar». A comienzos de 1912, la familia Miró cambia de domicilio, trasladándose desde la Avenida del Doctor Gadea al Paseíto de Ramiro, cuyas casas están situadas frente al mar (Ramos 1996: 349). No solo por fecha de publicación, sino por los sucesos biográficos aludidos, el relato, que en su inicio nos remite a un pasado ${ }^{16}$, está escrito en fechas inmediatas a las de su publicación, en marzo de 1912.

En el último cuento, «Relato de un viaje de novios», tanto el primer narrador - un «yo» que en su visita a una señora escucha ese relato- como después Sigüenza, son oyentes de la narración que una pareja de recién casados hacen de un suceso ocurrido en su viaje nupcial; aunque no son espectadores inocentes: saben ver en los detalles, comentarios, comportamientos y opiniones, las muestras de un egoísmo que, por cotidiano y convencional, pudiera pasar inadvertido, pero que resulta cruel para quien sabe entender. El relato es perfectamente sigüencino: un nuevo documento sobre el egoísmo humano y sobre la falsa piedad.

16 Parece que en este caso el escritor fecha aproximadamente ese viaje, el suceso relatado, pero no su escritura, ni el final, que es de importancia para entender su sentido. 
El profesor Márquez Villanueva (1990: 41-45) identificó su fuente: vendría a ser una reelaboración de la novela Lourdes, de Emile Zola, sometida por Miró a un proceso de concentración e intensificación. Pero también ambienta la velada en un interior confortable: la sala de una anciana señora donde los recién casados cuentan su viaje. Se trata de la narración de un suceso significativo - la muerte de un viajero que compartía el departamento del tren donde viajan los novios - dentro de un marco no menos significativo: una tertulia burguesa en una confortable habitación. Desde la seguridad de aquella costumbre se alude a una situación cruel que se intenta rebajar a la categoría de anécdota banal. Esta banalización de la muerte, como la falsa piedad que la señora dice sentir por los que padecen frío - y, como lo siente, pide otra toquilla - es una reducción de la vida a un concepto mezquino y estrecho, a una moral que convierte el egoísmo en comodidad, el padecimiento ajeno en molestia, y la muerte de un semejante en un sobresalto digno de ser contado como anécdota discordante en la felicidad del «viaje de novios».

Miró encontró en estos cinco relatos elementos comunes con la serie de Sigüenza, tal y como quedaba configurada en 1917, y los adaptó con facilidad y coherencia. En ellos está el sentido último de lo que encontramos en Del vivir, y que perdura hasta Años y leguas: modalidades del egoísmo; formas cotidianas de la crueldad que, por anodinas, no han de pasar inadvertidas; la falsa piedad y la relación que existe entre el goce de la naturaleza y una moral elevada sobre la mezquindad en el habitual trato social; la belleza del mundo, que mitiga los dolores y predispone a los afectos. Y, sobre todo ello, destaca la facilidad con la que el escritor traslada algunas de las opiniones, las vivencias y el carácter de un «yo», muy identificado biográficamente con el autor, a una tercera persona, a Sigüenza.

\section{SEgunda RECUPERACión, CON TRES RElAtos ADAPTADOS (1912-1913)}

A finales de noviembre de 1912, en las páginas de Los Lunes de El Imparcial, Sigüenza vuelve a aparecer después de dos años y medio de ausencia, y lo hace con nuevos rasgos. Es un personaje en el que reside el nervio del relato, e incluso genera su trama; un personaje que manifiesta opiniones firmes y que, por fin, tiene biografía: atisbamos una vida más allá del presente de la página, en cuyos datos reconocemos la de su autor. Al igual que Gabriel Miró, Sigüenza ha sido alumno interno en el colegio de Santo Domingo, que los Padres Jesuitas tienen en Orihuela, desde los ocho años; ha sufrido allí, y lo recuerda; es también padre de dos hijas, a las que quiere librar del padecimiento que él soportó. Tiene, pues, pasado — sabemos algo de su vida-, presente - padre de familia - y futuro, implícito en las hijas, y en sus criterios, que marcan un itinerario deseado por él. Es ya un personaje apto para protagonizar páginas más complejas que aquellas crónicas — escasas, además—, por exce- 
lentes que fueran. Dos de esas crónicas han sido recogidas en un libro que entonces acababa de ver la luz en Barcelona, Del huerto provinciano; su título está tomado del genérico con el que aparecían cuentos y crónicas suyas en Los Lunes de El Imparcial desde marzo de 1908 hasta el mismo mes del siguiente año, y después en Heraldo de Madrid desde abril de 1909 hasta ese mismo mes de 1910. En una nota inicial leemos unas frases que, en la descripción de sus «almas amigas», descubre el escritor sus propios sentimientos, su íntimo carácter:

Yo más quiero un mediano entendimiento y un corazón sencillo que mire las humildes hermosuras de la vida, que perciba sus menudas y escondidas sensaciones, y que como yo se contente aspirando el olor de la leña quemada y de la sembradura húmeda, y guste del silencio campesino, del vuelo de los palomos y de las gaviotas, de hollar las frescas tierras de los prados, del sueño de las nieblas de los ríos, y estremecerse de santo deleite asomándose a la Creación desde la soledad de una cumbre de serranía...

Yo escribo para esas almas amigas (Miró 2007: 121).

Las frases alusivas al carácter de Sigüenza con las que se inicia Del vivir («hombre apartadizo que gusta del paisaje y de humildes caseríos») responden a un ánimo similar: el mismo que quiere compartir el escritor con sus lectores. De esta manera, lo que encontramos en Sigüenza es un personaje en el que pueden reconocerse tanto el escritor como los lectores: un espíritu común, o mejor, un nombre a compartir entre su creador y su lector.

«El señor Cuenca y su sucesor» es el título afortunado que conserva el relato desde su aparición en Los Lunes de El Imparcial el 25 de noviembre de 1912. Afortunado porque ese «señor Cuenca» es el protagonista del relato que Sigüenza refiere al padre de «su sucesor», un niño callado, agobiado por la brutalidad de un progenitor insensible. Es uno de los relatos más afamados de su autor, y lo es con toda justicia. Hay aquí una excelente descripción del espacio (creación, mejor que descripción), una expresión del estado de ánimo, un análisis en la manifestación de sensaciones, una narración llevada en los términos justos y un final anticlimático.

El inicio, la soberbia descripción de la llegada en tren a Orihuela, guarda una digna simetría con el alejamiento de Oleza con que habrá de terminar, catorce años después, El obispo leproso. Pero la ciudad aquí es Orihuela, con sus huertas, sus templos, sus edificios monumentales sobresaliendo del conjunto de la ciudad, y el Colegio de Santo Domingo, con cuya imagen culmina un recorrido visual diseñado para terminar en el escenario de la acción.

Sabemos que en este texto se narra la llegada en tren de Sigüenza a esa ciudad levantina en compañía de un hacendado que va a ingresar a su hijo como alumno interno en el colegio de los Padres Jesuitas. Sigüenza recuerda las tristezas de su experiencia en el internado, y relata los últimos días de la vida de un niño débil y desvalido al que los Padres llamaban, según era de rigor en 
el trato, el «señor Cuenca». Es, pues, un relato, el de Sigüenza, dentro de otro relato en tercera persona, pero ceñido a la figura del protagonista: vemos lo que él va viendo y sabemos lo que va sintiendo. El regreso al lugar suscita complejas sensaciones que resucitan las de los años de la infancia:

Sigüenza contemplaba la tarde angustiado, enfermo de tristeza, una tristeza tan acerba, tan densa, que le parecía que no era sólo un sentimiento suyo, sino que tenía una realidad propia, separada, grande, más fuerte que nuestra alma; la tristeza se le incorporaba de todo lo que veía, porque la vega, sus humos, sus árboles, los montes y el cielo, todo estaba hecho, cuajado de tristeza; la misma que le oprimía siendo chiquito, cuando, vestido de uniforme de colegial, salía con su brigada, la de los pequeños, por aquellas sendas, aguardando el paso del tren, un tren que le traía tantas memorias alegres, que aún le entristecía más que el paisaje y el regreso al Colegio de Santo Domingo (Miró 2008: 485).

La memoria le hace revivir unos sentimientos que adquieren objetividad física y, al igual que él se ve en su recuerdo, los lectores lo vemos vestido de colegial y ocupando su lugar en las brigadas. El relato tiene gran fuerza patética y lírica, y es reconocido su componente crítico, como denuncia de una disciplina deshumanizada. La fragilidad del «señor Cuenca» — más acentuada al ser designado con enfático tratamiento-, su resignada aceptación de los castigos, sin entenderlos, su desaliño..., son una conmovedora imagen del desvalimiento y de la fragilidad, más conmovedora en su vida que en su muerte. El relato ocupa un digno lugar en una época en que la crítica al sistema educativo de los Jesuitas dio materia para diversas obras literarias: A.M.D.G., de Ramón Pérez de Ayala, y El obispo leproso son las de mayor calado en nuestra literatura - fuera de ella, destaca el Retrato de un artista adolescente, de James Joyce_-; pero este cuento es certero, estéticamente hablando, y eficaz en el ámbito de la ética. Justo y preciso, aunque rozando el sentimentalismo, es la expresión de una niñez — la de Sigüenza, la de Miró-, agobiada por la frialdad en el trato y traspasada por una soledad en la que hubo de sentir, según confiesa, «las primeras tristezas estéticas» ${ }^{17}$.

El relato sobre la niñez desvalida aparece como la segunda pieza en las dos versiones del Libro de Sigüenza; en la de 1927 se le añade entre paréntesis el subtítulo «Enseñanza», para formar parte de la primera sección titulada «Capítulos de la Historia de España», marcados por una actitud crítica, irónica y acre. En las dos versiones, el libro se abre con el mismo relato que — este sí- cam-

17 En la carta que escribió Miró, en marzo de 1906, a Andrés González Blanco, y que fue reproducida por éste al final del capítulo que le dedica en Los Contemporáneos, leemos: «No olvido nunca mis largas temporadas pasadas en la enfermería de un colegio de Jesuitas, desde cuyas ventanas he sentido las primeras tristezas estéticas, viendo en los crepúsculos, los valles apagados y las cumbres de la sierra aún encendidas de sol» (González Blanco 1906: 290-291). 
bia su título en cada una de sus tres primeras apariciones: «Sigüenza, opositor», se llama en 1913; «Un capítulo de la Historia Judicial de España» en 1917, y por fin «El señor de Escalona (Justicia)», que es como lo conocemos (1927). Es interesante ver esta transformación desde el título inicial, más escueto y preciso, más denotativo - trata sobre las oposiciones a judicatura a las que se presenta Sigüenza-; uno segundo, plenamente irónico, punto de partida para designar al conjunto de cinco relatos con los que ha de formar esa primera sección en 1927, y, por fin, la mención del personaje con el que Sigüenza comparte protagonismo (como en el relato del «señor Cuenca», es el otro personaje que aparece junto a él quien lo sustituye en el título). La ironía aumenta, ya que el título nobiliario de «señor de Escalona» hace pensar en el infante don Juan Manuel. Iniciar con este capítulo el Libro es un acierto, por su carga biográfica, por su ironía y su ternura, además de lo sutil e inteligente de su crítica; lo que no hubiera sido lo mismo de haberlo iniciado con el de la infancia, más adecuado, si atendemos a criterios biográficos, pero menos indicado, puesto que su patetismo y sentimentalismo no lo hace umbral idóneo para este libro. Es significativo que el componente crítico que hay en la obra de Miró no suela ser destacado ${ }^{18}$, y no lo ha sido porque el escritor siempre ha rehuido todo aspaviento para privilegiar las sugerencias, y de ello hay aquí mucho más que en el relato con el que inicia esta tercera recuperación.

Miró decide al final, en la tercera versión de un texto muy poco retocado — presenta escasas variantes en sus tres primeras salidas - dar el protagonismo en el título al conmovedor "señor de Escalona», el modesto hacendado castellano, compañero de oposiciones de Sigüenza y fracasado como él. Es evidente que Gabriel Miró ha construido este relato con materia biográfica: las oposiciones a Judicatura a las que se presentó, sin éxito, en 19079; de ahí la fecha que el escritor puso a un relato publicado inicialmente en Diario de Barcelona en febrero de 1913 y que, con seguridad, sería redactado por aquellos días. Esto explica que en el primer párrafo el escritor se refiera al pasado: «En la primera mocedad de Sigüenza, algunos amigos y familiares le dijeron [...]» (Miró 2008: 479). Sigüenza, como su autor, es abogado, tiene «mujer, hijas y padres viejos», carece de empleo y marcha a la capital de España para presentarse a

${ }_{18}$ Con alguna notable excepción, como las de Díez de Revenga (1979) o Rubia Barcia (1979), sin olvidar los trabajos fundamentales de López Landeira (1972) o de Roberta Johnson (1985).

19 Sabemos que Gabriel Miró se presentó dos veces a oposiciones a Judicatura: en la primera (1905) fue aprobado sin plaza; en esta segunda, en la que fue suspendido, el viaje a Madrid le sirvió para enterarse de la convocatoria del concurso cuyo premio le daría fama nacional; véase José Guardiola Ortiz (1935: 96-97). La fecha que atribuye al relato en 1927 corresponde a las segundas oposiciones, así como el dato biográfico de tener hijas, puesto que, en los días de sus primeras oposiciones, su hija menor, Clemencia, todavía no había nacido. 
oposiciones en las Salesas. La escena central, en Madrid, tiene su preámbulo en los primeros párrafos, donde se resalta la inocencia del personaje, su carácter vulnerable y su falta de voluntad (humorísticamente, se resigna a ser juez). Es la mejor presentación para un personaje al que vamos a ver, en el libro que se le dedica, desenvolviéndose en diversas situaciones a lo largo de treinta y dos capítulos.

El ambiente en el lugar de las oposiciones está mostrado de manera magistral y concisa: los tipos humanos, el espacio físico, la grisura de un día lluvioso invadiéndolo todo... La llegada del lugareño de Escalona a lomos de un pollino, su desvalimiento y la tosquedad de su atuendo, marcan una disonancia con el ambiente. De entre todos, este personaje elige a Sigüenza para acercarse, informarse y conversar, tal vez porque adivinó en él a «un camarada lugareño» - como apunta el narrador-, o porque reconoció una humanidad que no veía en los demás. Efectivamente, son almas semejantes que se acompañan en su soledad.

En el desenlace, Sigüenza, que acaba de formar parte de un jurado en la Audiencia de su ciudad, escribe al de Escalona para relatarle la experiencia: ellos, que iban para jueces, ejercen desde el jurado; un jurado a cuyos miembros un «licenciadito» con toga llamó «sacerdotes», ya que «les estaba encomendada una augusta, una sagrada misión»; pues a estos sacerdotes los mantuvo al pie de la escalera, prohibiéndoles la entrada hasta que llamaran, «un ujier menudo, trasijado, con botas de paño, grandes, dobladas, siniestras, de difunto, y la casaca raída, calva, demasiado holgada, de difunto también» (Miró 2008: 483). Pero, con todo, deben estar orgullosos, pues han participado «en un capítulo de la Historia de España» (ibid.: 484).

Una continuidad con el Sigüenza andariego, el que viaja, observa y medita, la encontramos en «Un envidiado caballero». La anécdota es mínima, y está precedida por una especie de preámbulo significativo: una descripción en la que el paisaje y el ambiente observado preparan y completan la ironía que hay en el título. Sigüenza llega a una hermosa villa labradora y marinera, con gorriones y gaviotas, humos campesinos y nieblas de mar $^{20}$. El personaje siente intensamente las gracias del pueblo: «Los olores de las huertas y del mar llegaron hasta el corazón de Sigüenza. Miraba y aspiraba este hombre con tanto ímpetu, que llegó a sentir cansancio y dolor en su carne» (Miró 2008: 569). En medio de tanto halago a los sentidos, se fija en las casas donde hay enfermos: viejos enjutos, jóvenes demacrados por la terciana, tullidos «de dolores recogidos en el mar», lisiados, idiotas... Son casas «señaladas por una mano aciaga» (ibid.: 571). Es un primer contraste, al que ya estamos acostumbrados

${ }^{20}$ El hecho de que no figure el nombre de la localidad indica que el escritor no tiene intención de escribir unas páginas costumbristas, ni colaborar en el «regionalismo» esteticista cantando las bellezas del lugar; su intención es otra, y procura que un posible interés localista no desvíe la atención del lector hacia lo periférico. 
desde Del vivir: el dolor en medio de la belleza. Pero el nuevo contraste aparece con el personaje aludido en el título, un caballero «envidiado» a causa del éxito de su familia. Todos están de acuerdo en encomiar la suerte de don Luis: es una «familia de elegidos» la suya; su hija es una artista que peregrina, acompañada por su madre, por los teatros de América, «ocho años hacía que no las viera»; un hijo era concertista, «en ruta gloriosa», y el otro comenzaba a tener éxito en Roma. Todos hablan con admiración al «envidiado caballero», quien solo puede compensar su triste soledad escuchando en un gramófono la voz de su hija, o siendo confortado por la belleza del paisaje, en el que refugia su mirada cuando le vence el desaliento. La de don Luis es también una casa de tristeza, aunque no sea tan evidente como la de aquellas en donde hay un enfermo. El éxito y los sucesos prósperos conducen también al «dolorido sentir», como muy bien sabe este «envidiado caballero de Levante».

Otro contraste encontramos en una especie de crónica, la que abre en 1927 la sección «Muelles y mar», titulada «Una mañana». Sigüenza, otra vez a la manera de un flâneur, pasea por el puerto alicantino, disfrutando del espléndido sol y distrayéndose con la observación del tráfago ordinario. Se fija en un hombre descomunal que está dirigiendo la carga de un buque negro y grueso, como él, que engulle en sus bodegas toneladas de hortalizas; en medio de la luminosa mañana parece que se sintiera grande y fuerte, «manifestaba la hermética soberanía de un ídolo cartaginés» (Miró 2008: 508). Como contraste, Sigüenza se encuentra con un archivero menudo, un erudito ingenuo y manso, vestido con un gabán de 1870. Este hombre, templado y humilde, lo opuesto al rollizo fenicio, parece que también acusa el poder de la mañana levantina cuando se transfigura, irritado, ante la queja de los invernantes, que encuentran la ciudad carente de elegancia y diversiones. El modesto archivero, irritado, replica que les damos lo que necesitan: «inuestro sol, todo el sol que quieran!», como si él mismo lo repartiera, sacándolo de «las mustias faltriqueras de su gabán color de pasa de 1870» (ibid.: 509). Una anécdota reveladora de la vida provinciana.

«Una tarde» es un texto especialmente representativo del arte y del mundo mironiano, dentro de la serie de Sigüenza. Es una crónica de emociones y desengaños. Encontramos aquí los elementos más característicos: la atención a la conciencia del personaje; una descripción del espacio, donde alcanzan plenitud las sensaciones sensoriales y los sentimientos e ideas que la belleza engendra en un personaje sensible; una propensión a lo meditativo; una sucesión de escenas significativas, preparadas para llegar a una conclusión; un leve hilo narrativo que ha de culminar con un suceso; el diseño del asunto en torno a unos contrastes bruscos, y el tema de la crueldad con los animales. En el inicio, con la descripción de la belleza en su plenitud, la tarde no se nos presenta solo como un escenario, un fondo para la acción, sino como un elemento fundamental del tema: 


\begin{abstract}
Nunca tuvo nuestro mar la pureza, la alegría y quietud de esa tarde.
Sigüenza vio algunas gentes asomadas a los balcones. Todas le parecieron comunicadas de la gracia infantil, de la inocencia antigua del Mediterráneo. Si pasaba algún barco de vela, se veía todo su dibujo primorosamente calado sobre el cielo y las aguas. La isla de Tabarca, que siempre tiene un misterio azul de distancia, como hecha de humo, mostrábase cercana, clara, desnuda y virginal.

Las gaviotas parecía que volasen en un recinto guardado entre dos cristales: el del cielo y el del mar, porque el mar estaba tan liso, tan inmóvil, como si se hubiera cuajado en una delgada lámina y bajo de ella no hubiese más agua, sino el fondo enjuto, alumbrado de sol (ibid.: 509-510).
\end{abstract}

Sigüenza decide pasear por el puerto junto a un amigo. Los sentimientos de «amor a todos» que aquel ambiente despierta en él le llevan a imaginar un Paraíso en el que Dios hubiera creado «muchos primeros padres al mismo tiempo», y a pensar que aquella sensación de beatitud llevaría a los hombres a bendecir a los artistas. Una recovera que vendía en el puerto llama la atención de Sigüenza; él la conoce: es la proveedora de huevos y de averío de la Diputación, de donde él es cronista. La vendedora, que ignora el significado de esa palabra, se ríe a carcajadas cuando le explican que «aquello era oficio de escribir libros de historia y de fantasía», no entendiendo que con semejante oficio pudiera ganarse la vida. Una primera ilusión decepcionada: aquella mujer ni amaba ni respetaba a los artistas, pareciéndole la de Sigüenza una actividad ridícula.

Una nueva escena sucede a esta: Sigüenza ve un grupo de niños jugando con un perrito, al que acariciaban y daban de sus meriendas, y entiende que este grupo «participaba de la inocencia y de la buena alegría de la tarde», lo que le hace olvidar las palabras de la recovera. El final redondea el contraste fraguado desde el inicio, con una mayor decepción y una enseñanza. Si en los primeros párrafos se hablaba de la «gracia infantil» y de la «inocencia antigua del Mediterráneo», es porque esa inocencia la vemos también en la manera en que los niños atan una piedra al cuello del perro y lo hunden en el agua hasta que se ahoga: porque el mar estaba tan trasparente que les provocó la curiosidad de «ver como se ahogaba un perro y todo lo que hacía...» (ibid.: 509). De nuevo el contraste entre la belleza, que engendra el sentimiento de amor a todos, y la crueldad espontánea. El tema planteado en el inicio, los efectos de la belleza en el ánimo del hombre, se completa aquí con el efecto que produce en los niños quienes, por la quietud y transparencia de las aguas, matan «sin querer» al perrillo al que habían tratado con cariño. El tema de la crueldad espontánea en la infancia ya lo había introducido Miró en el inicio de Del vivir, en una escena donde unos patos son apedreados solo por haber sido contemplados cariñosamente por Sigüenza, causante involuntario del comportamiento de aquellos niños.

Este relato —o crónica de una hermosa tarde - aparece introducido aquí porque estimo que es el lugar adecuado; debe pertenecer a este período y se 
inserta entre «Una mañana»y «Una noche», como su lugar natural. «Una tarde» no lo hemos encontrado publicado hasta 1917, en la primera versión del Libro. En la segunda (1927) el autor le añade al final la fecha de 1909. Es posible que permaneciera inédito, aunque es extraño que hubiera guardado un texto así; pero admito como más segura la posibilidad de que hubiera visto la luz años atrás, en alguna publicación periódica que desconocemos por ahora.

La fecha de 1909 debe participar de la condición de incierta que tienen las añadidas en 1927 al final de cada capítulo. Hay en el texto un dato que pudiera ayudarnos: el narrador presenta a Sigüenza como Cronista de la Diputación. Miró lo fue desde octubre de 1909 hasta que fue cesado en febrero de 1910, lo que viene a coincidir con la fecha que el escritor puso en la edición de las Obras Completas de Biblioteca Nueva, aunque intuimos que lo pudiera fechar recordando de manera aproximada la época del acontecimiento aludido o su circunstancia, no el momento de la escritura. Pero sabemos también que Miró fue repuesto en el cargo de cronista, y que tomó posesión en enero de 1912, manteniéndose en él hasta 1919, después de residir casi seis años en Barcelona. Si estimamos que el dato puede ser un elemento clave para fechar el texto, este podría haber sido escrito o en el breve período 1909-1910, o en el segundo período, desde enero de 1912 hasta que abandona Alicante, en febrero de 1914, por ser ese el lugar de la acción. De las dos posibilidades estimo como más plausible la segunda. Es un texto más maduro y vigoroso que las primeras crónicas. Si hubiera aparecido en aquella época, es probable que hubiera sido recogido en Del huerto provinciano, ya que es mejor que los dos que allí aparecen. Sencillamente: si no forma parte de este libro es porque aún no existía. Creo que su lugar está entre los textos de 1912-1913, no muy lejos de «Una mañana» y del que comentamos a continuación.

Sigüenza alcanza otro tipo de protagonismo cuando se convierte en el causante de una imprevisible desgracia: es el que de manera involuntaria e inocente hace brotar la violencia y la crueldad. «Una noche (En Cristianía)» lleva en su primera salida como título lo que en la versión definitiva figura entre paréntesis. Los sueños de viajes de Sigüenza se reducen a un simulacro al conseguir ser invitado a cenar por el capitán de un buque noruego fondeado en el puerto de Alicante. En el camarote se hace la ilusión de encontrarse muy lejos, en las tierras nórdicas; pero va sumando decepciones: una sopa azucarada, peces hervidos y bañados en jarabe de frambuesa, que no son de su gusto - pero es lo que comerían Ibsen o Grieg_- y un vino muy leve, que imagina producto de viñas tristes, sin sol ni calor. La verdad es que el vino fue comprado en una tienda del puerto, y es la causa por la que se desata un violento motín a bordo, descrito con crudeza. «En Cristianía» — nombre que entonces tenía la actual Oslo, pero que alude también a una religión cuyo mandamiento central es el del amor al prójimo - no sucede lo esperado; frente al ideal de placidez y melancolía que en la mente de Sigüenza suscitan las tierras nórdicas, la realidad le muestra un comportamiento brutal: unos hombres que se convier- 
ten en fieras al disputarse las sobras del vino comprado para agasajar a Sigüenza. Como en el relato «Plática que tuvo Sigüenza con un capellán», se produce ese «hecho» de apariencia nimia, que despierta la violencia dormida en los hombres.

La crueldad aparece en varios de los relatos de este período, y de manera señalada la crueldad con los animales. Dentro de esta temática, constante en la obra de Miró, destacan aquí cuatro títulos: «De la crueldad de Sigüenza», «Un artículo de Sigüenza», «Sigüenza, el ganado y el cordero», a los que hay que añadir «Una tarde», al que ya nos hemos referido.

El primero de estos textos no fue recogido en el Libro. Clemencia Miró lo recogió en Glosas. Trata sobre las consecuencias involuntarias de una inocente curiosidad naturalista: observar las reacciones de una araña capturada en un tarro, y luego las de un escorpión..., y todo esto da como resultado escenas crueles, que culminan con la diversión de las gentes, quienes esperan con gozo el suicidio del escorpión al verse rodeado de fuego. La crueldad está en todo el reino animal, y culmina en el hombre. Es uno de los pocos relatos en primera persona, con un dato curioso: Sigüenza asegura que aquellas observaciones las hizo en un tiempo pasado, antes de leer Antonio Azorín.

Más famosa es la segunda narración, que a partir de 1917 se titula «Una jornada del tiro de pichón», crónica minuciosa sobre este entretenimiento, calificado de «deporte» en la buena sociedad, y presenciado por los niños, a los que se inicia en esta crueldad aceptada y valorada como deporte inocente y saludable. El tono es de crítica acre. Sigüenza se indigna ante un espectáculo que muestra la insensibilidad de la sociedad ante el dolor y la muerte de animales ofrecida como diversión y presentada a los niños como una fiesta. El tercer relato modifica de manera leve el título a partir de 1917: «Sigüenza, el pastor y el cordero»; un relato narrado como un recuerdo - tal vez por eso le asignó la fecha de 1903-: la estancia en una masía en las sierras de Alcoy le lleva a ser testigo de cómo un pequeño cordero es el precio que un pastor paga por la utilización de los pastos a los dueños de esa finca. La descripción del sacrificio del cordero es descrita con crudeza y minuciosidad naturalista; por ese sacrificio goza de alimento el rebaño; y hasta el mismo Sigüenza, que presencia la muerte y el descuartizamiento del animal, se siente bueno, y lo ama todo, gracias a la digestión de la sabrosa carne.

Otro extremo de crueldad es el inculcado en los niños por los malos tratos de sus padres. «Cosas viejas y sabidas» es un texto no recogido por el escritor, pero de notable interés. Viene a ser una especie de relato ensayístico de asunto relativo a la moral social y a la psicología. Sigüenza, que disfruta de la belleza del mundo mediante sus sentidos, experimenta una suerte de «reciprocidad beatísima» entre su alma y la naturaleza; pero ese sentimiento no alcanza plenitud, pues este — piensa Sigüenza - ha de ser un «fenómeno social». Entendemos su sentido cuando vamos viendo la serie de escenas crueles, sin dejar de ser cotidianas, que se presentan ante él en ese día: «Estas ferocidades 
[reflexiona nuestro personaje] que algunos sabios han seguido hasta perderlas en el fondo ciego, instintivo del hombre, ¿no se habrán hecho fisiológicas, fatales, por imitación y por la imitación en el hogar?»» ${ }^{21}$

Tres de los relatos de este período no pertenecían, en su primera versión publicada, al ciclo de este personaje: son, de nuevo, adaptaciones a la experiencia de Sigüenza de sucesos que habían sido narrados en primera persona, como hemos visto con otros en el anterior apartado. «El pececillo del Padre Guardián» era un relato, narrado en primera persona del plural, de un viaje que un grupo de amigos hace al convento de Orito, edificio abandonado para cuya restauración y recuperación había sido enviado, en aquellos días, un grupo de frailes capuchinos. El convento, deteriorado y carente casi de mobiliario y de menaje, tiene junto a él una huerta, con su balsa, que fueron enajenadas. La huerta es el único espacio con vegetación abundante en medio de un enorme secarral. El convento necesitaría la huerta para su provisión, pero el buen fraile que les guía, el padre Guardián, jovial y emprendedor, como buen discípulo de San Francisco, no pide la balsa - y con ella la huerta anexa - para la comunidad, sino para el pececillo que vive estrechamente en un frasco de cristal. «Este pececillo es mi estímulo», dice el fraile, quien termina rogando a Sigüenza - o al narrador, en la primera versión - que encamine sus oraciones de manera adecuada: «Hijito, hijito, no piense en mí; pida, pida la balsa para el pececillo!...» (Miró 2008: 502).

Los otros dos relatos adaptados formaban parte de una breve serie con rótulo genérico, «Figuras», que ha de dar como resultado, a partir de la Semana Santa de 1914, la serie con la que habrá de formar sus Figuras de la Pasión del Señor. La primera, «Figuras que todos conocemos.-La señora que hace dulces», es un cuento de ambiente cercano a Las cerezas del cementerio (ambiente de vacaciones estivales; relaciones afectuosas del joven protagonista con su prima; atracción por una bella dama madura, a la que juzga desdichada...). Relatado en primera persona en origen, adopta la tercera en el Libro para contar la visita de Sigüenza, joven, a casa de su tía y de su prima. Le hablan de Victoria, la señora de Olóriz, mujer de mucha habilidad en repostería y amante de la elaboración de dulces muy celebrados, a la que van a visitar. La descripción de la señora es un ejemplo relevante de sensualidad:

Una señora muy blanca, de carne de almendra, de ojos dorados con una leve humedad de hoja de flor; toda es suave, aterciopelada; cuando os mira, sentís una caricia blanda de hermana, de una mujer bella que no es vuestra hermana; y cuando habla, imagináis su garganta tapizada de rosas gruesas; es una voz pastosa, y todo lo que pronuncia tiene figura y un contorno de sonido tierno, tan gustoso que lo recogéis en todo vuestro cuerpo, y os quedáis paladeando sus mismas palabras como un dulce exquisito (Miró 2008: 553).

${ }^{21}$ Recogido por Marta E. Altisent (1992: 168). 
Al igual que Félix Valdivia ante la señora de Giner, el protagonista, Luis en la primera redacción y Sigüenza en la segunda, piensa que esta mujer, hermosa y atractiva, toda encantos, es desdichada. Cuando al final parece que va a ser destinatario de una confidencia que espera con ansiedad, la hermosa señora de Olóriz lamenta, con una cierta congoja, que no pueda probar sus meladas, que tanto agradan al obispo. La decepción conduce el relato hacia la restauración de la normalidad. El encanto se rompe, aunque no de manera cruel, como en la novela.

«Figuras de nuestra vida.-El señor de los ataques» es una evocación de personas a las que el narrador conoció en el pasado. Alrededor de la figura de un viejo dandy, que va padeciendo el inevitable proceso de deterioro, se reconstruye el ambiente de la ciudad durante la juventud de Sigüenza —en la versión del libro, modificando la anterior, en primera persona-. Los ataques de aquel hombre, que murió hace tiempo, y de quien ya les cuesta acordarse, sirven para fechar sucesos de sus vidas. El sufrimiento de los demás es un proceso paralelo a los júbilos de la juventud, un padecimiento ajeno al que se asoman, cuando lo hacen, más por curiosidad que por compasión.

Si dejamos para el final «Los almendros y el acanto» es por su sentido filosófico y moral. Es una especie de parábola, cercana al ensayo, sobre los ejemplos y enseñanzas que extraemos de la naturaleza; pero también sobre su carácter ambiguo, cuyo sentido dependerá de nuestros pensamientos y afectos. Como en Hilván de escenas, los almendros, con su frágil floración y su delicado fruto tierno, es un ejemplo de cómo han de malograrse muchas ilusiones antes de obtener un resultado. El almendro nos da ejemplo de sufrimiento y de abnegación. El acanto presenta a Sigüenza dos caras, dos posibilidades: la emoción de Grecia - la belleza representada en la evocación- o lo que unos personajes le van diciendo de la planta: un mercader la llama «hierba carnera», buena para los dolores de estómago; un amigo le dice que es buena para los vicios de la sangre, y un abogado, que para curar los romadizos. Sigüenza decora con sus hojas su habitación de trabajo, y desconfía - «¿será hierba carnera?»—. Tiene momentos de desaliento, pero cuando recupera su ilusión, recuerda la lección del almendro, y «la mata carnera fue acanto perenne, glorificado por la noble gracia legendaria» (Miró 2008: 548). La belleza del objeto depende de nuestro concepto y de nuestro ánimo, de nuestra decisión ${ }^{22}$ : nosotros embellecemos estas hojas si nos empeñamos en ver su belleza. La «verdad de la belleza» es, en buena medida, el resultado de un cometido personal $^{23}$, un hallazgo y una decisión: como Grecia hizo con una «hierba carnera»

${ }^{22}$ Encontramos en este texto una primera formulación de lo que será un criterio de madurez que sustenta su obra mayor Años y leguas: cualquier objeto de nuestra experiencia es como es "por nuestro concepto, por nuestro recuerdo, por nuestra lírica», leemos en sus últimas páginas (Miró 2008: 804-805).

${ }^{23}$ Es lo que persigue y consigue el artista a partir de elementos tomados de «la realidad, con todas sus exactitudes», como reitera en su conferencia «Lo viejo y lo santo en manos 
de posibles utilidades prácticas un hermoso capitel. Esta página, bella e intensa, es toda una reflexión sobre la eficacia de nuestro noble empeño en la creación y reconocimiento de lo bello.

Estos que acabamos de consignar y de comentar son los primeros textos de un Sigüenza que ha ingresado en la madurez. El último muestra unas ideas que han de ir desarrollándose hasta su plenitud, al final de Años y leguas. Pero buena parte de ellos nos remiten a un pasado, a la juventud del personaje: el pasado está con mucha claridad en «El señor de los ataques», «En Cristianía», «De la crueldad de Sigüenza», y un pasado ajeno y luego acomodado aparece en «La señora que hace dulces». Pero más explícitos en esta alusión y recreación del pasado desde la madurez son los dos capítulos iniciales del Libro (en sus dos versiones): «Sigüenza, opositor», o «El señor de Escalona», recrea un episodio, inventado o modificado, de la juventud del personaje, con un fragmento final que remite a "años después», en el que un Sigüenza maduro escribe esa carta de jugosa ironía tras su experiencia como miembro de un jurado. Más claro y evidente es el juego temporal en «El señor Cuenca y su sucesor»: aquí, un protagonista maduro, padre de familia, recuerda este episodio de su infancia, y revive en la memoria la experiencia del internado. Sigüenza tiene un pasado que enjuicia, asume y le sirve de enseñanza.

A partir de diciembre de 1913 Miró comienza a publicar en La Vanguardia. Aquí el personaje ya va a tener una serie propia, «Jornadas de Sigüenza», que cuatro meses después acentuará su componente ensayístico con una ampliación en el título: «Jornadas y comentarios de Sigüenza» ${ }^{24}$. Es el más claro resultado de su consolidación y, por ende, de la singularidad de unos textos derivados de su presencia. Sigüenza es un logro literario cuya importancia todavía no hemos sabido entender de manera adecuada: un ente de materia verbal y sustancia ético-estética en el que su autor puede objetivar sus «emociones» y trascender del asunto privado a la «evocación y aun resignación en las cosas que a todos nos pertenecen» (Miró 2008: 477); es un nombre a compartir entre escritor y lectores: un personaje que nos permite contemplar la compleja incertidumbre que es nuestra vida desde la certeza de nuestras limitaciones.

\section{BIBLIOGRAFÍA CITADA}

Altisent, Marta Eulalia (1992). Los artículos de Gabriel Miró en la prensa barcelonesa (1911-1920). Madrid: Editorial Pliegos.

de ahora» (1925), y en dos de los borradores de «Sigüenza y el mirador azul», redactados a comienzos de 1927 y editados por Edmund L. King (Miró 1992).

${ }^{24}$ Esta colaboración en el diario barcelonés se extiende desde el 9 de diciembre de 1913 hasta el 26 de junio de 1914, en que el personaje vuelve a desaparecer. Entre estas fechas se publican dieciocho crónicas, de las que trece pasarán al Libro. Este breve período ha sido estudiado por Lozano Marco (2014). 
Cansinos-Assens, Rafael (1925). La nueva literatura. II. Las escuelas. Madrid: Editorial Páez.

Díez de Revenga, Francisco Javier (1979). «Gabriel Miró y España a través de unos capítulos de su historia», Revista del Instituto de Estudios Alicantinos. 27, pp. 117-122.

González Blanco, Andrés (1906). «Gabriel Miró», en Los Contemporáneos. Primera serie. París: Garnier, tomo II, pp. 276-292.

Guardiola Ortiz, José (1935). Biografía intima de Gabriel Miró (El hombre y su obra). Alicante: Imprenta Guardiola.

Guillén, Jorge (1969). Lenguaje y poesía. Madrid: Alianza Editorial.

Johnson, Roberta (1985). El ser y la palabra en Gabriel Miró. Madrid: Fundamentos.

King, Edmund L. (1999). «Gabriel Miró, autor», en R. M. Monzó y M. A. Lozano Marco (eds.), Actas del I Simposio Internacional Gabriel Miró. Alicante: CAM, pp. 29-40.

López Landeira, Richard (1972). Gabriel Miró: Trilogía de Sigüenza. University of North Carolina, Department of Romance Languages.

Lozano Marco, Miguel Ángel (1979). «En torno a Los pies y los zapatos de Enriqueta, novela corta de Gabriel Miró», en Juan Luis Román del Cerro (coord.), Homenaje a Gabriel Miró. Estudios de crítica literaria. En el centenario de su nacimiento (18781978). Alicante: Publicaciones de la Caja de Ahorros Provincial, pp.101-122.

Lozano Marco, Miguel Ángel (2005a). «Gabriel Miró, Del vivir (1904) y su ruptura con la convención novelesca», Revista de Literatura. LXVII, 134, pp. 483-500. https://doi. org/10.3989/revliteratura.2005.v67.i134.104

Lozano Marco, Miguel Ángel (2005b). «Libro de Sigüenza en sus dos versiones (1917 y 1927). Las "Nuevas jornadas"», Canelobre. 50, pp. 149-163.

Lozano Marco, Miguel Ángel (2014). «Gabriel Miró en 1914. Sus colaboraciones en La Vanguardia», Monteagudo. 19, pp. 73-92.

Mainer, José-Carlos (1975). La Edad de Plata. Barcelona: Los Libros de la Frontera.

Márquez Villanueva, Francisco (1990). La esfinge mironiana y otros estudios sobre Gabriel Miró. Alicante: Instituto de Cultura Juan Gil-Albert.

Miró, Gabriel (1952). Glosas de Sigüenza. Buenos Aires: Espasa Calpe Argentina, S. A.

Miró, Gabriel (1992). Sigüenza y el Mirador Azul y Prosas de "El Ibero», introducción biográfica, transcripciones y enmiendas de Edmund L. King. Madrid: Ediciones de La Torre.

Miró, Gabriel (2006, 2007 y 2008). Obras Completas, ed. M. A. Lozano Marco. Madrid: Fundación José Antonio de Castro, tres volúmenes.

Miró, Gabriel (2009). Epistolario, ed. Ian R. Macdonald y Frederic Barberà. Alicante: Instituto Alicantino de Cultura Juan Gil-Albert, CAM.

Ramos, Vicente (1996). Vida de Gabriel Miró. Alicante: CAM, Instituto de Cultura Juan Gil-Albert.

Rubia Barcia, José (1979). «La radical esencialidad de Sigüenza», en Juan L. Román del Cerro (ed.), Homenaje a Gabriel Miró. Estudios de crítica literaria. Alicante: Publicaciones de la Caja de Ahorros Provincial, pp. 35-52.

Torres Nebrera, Gregorio (1995), «Introducción», en Gabriel Miró, Corpus y otros cuentos. Alicante: Instituto de Estudios Juan Gil-Albert.

Fecha de recepción: 9 de febrero de 2016.

Fecha de aceptación: 3 de noviembre de 2016.

Revista de Literatura, 2018, vol. LXXX, n. ${ }^{\circ} 160,463-490$, ISSN: 0034-849X

https://doi.org/10.3989/revliteratura.2018.02.018 